\title{
PENGARUH TINGKAT INFLASI DAN TINGKAT PERTUMBUHAN EKONOMI TERHADAP UPAH MINIMUM REGIONAL (UMR) DI PROVINSI BALI PADA TAHUN 2008-2015
}

\author{
Luh Kertiasih \\ Jurusan Pendidikan Ekonomi \\ Universitas Pendidikan Ganesha \\ Singaraja Indonesia \\ e-mail: Kertiasih6@gmail.com
}

\begin{abstract}
Abstrak
Penelitian ini bertujuan untuk mengetahui (1) pengaruh tingkat inflasi terhadap UMR di Provinsi Bali pada tahun 2008-2015, (2) pengaruh tingkat pertumbuhan ekonomi terhadap UMR di Provinsi Bali pada tahun 2008-2015, dan (3) pengaruh tingkat inflasi dan tingkat pertumbuhan ekonomi secara simultan terhadap UMR di Provinsi Bali pada tahun 2008-2015. Penelitian ini termasuk dalam jenis penelitian kausal dengan pendekatan kuantitatif. Subjek dalam penelitian ini adalah Provinsi Bali dan objek dalam penelitian ini adalah tingkat inflasi, tingkat pertumbuhan ekonomi dan UMR di Provinsi Bali. Metode pengumpulan data yang digunakan dalam penelitian ini adalah metode dokumentasi. Data yang sudah diperoleh dianalisis dengan menggunakan uji regressi variabel dummy dengan bantuan program statistical package for social sciences (SPSS) for windows versi 16. Hasil penelitian menunjukkan bahwa (1) tingkat inflasi tidak berpengaruh signifikan terhadap UMR, hal ini dapat dilihat dari hasil uji signifikansi dengan uji $t$ diperoleh nilai t.hitung lebih kecil dari t.tabel yaitu $-0.079<2.0369$ dengan nilai signifikansi $0.938>0.05$, (2) tingkat pertumbuhan ekonomi tidak berpengaruh signifikan terhadap UMR, hal ini dapat dilihat dari nilai t.hitung yang lebih kecil dari nilai t.tabel yaitu $-0.151<2.0369$ dengan nilai signifikansinya sebesar $0.881<0.05$, dan (3) tingkat inflasi dan tingkat pertumbuhan ekonomi secara simultan tidak berpengaruh signifikan terhadap UMR, hal ini dapat dilihat dari hasil uji signifikansi dengan uji $F$ diperoleh nilai $F$.hitung lebih kecil dari nilai F.tabel yaitu $0.015<4.17$ dengan nilai signifikansi $0.985<0.05$.
\end{abstract}

Kata kunci: Tingkat inflasi, tingkat pertumbuhan ekonomi, UMR

\begin{abstract}
This research aims to know (1) the influence of inflation to minimum wage in Bali Province in 20082015, (2) the influence of economic growth of minimum wage in Bali Province in 2008-2015, and (3) the influence of the inflation rate and the growth rate economic simultaneously to the minimum wage in the Province of Bali in 2008-2015. This type of research is included in the types of causal research with quantitative approach. The subject in this study is the Province of Bali and the object of this research is the inflation rate, economic growth rates and the minimum wage in the province of Bali. The data collection method used is the documentation. Data obtained will be analyzed by regression analysis with dummy variables using the Statistical Program Socila Scene (SPSS) 16.0 for windows. The results showed that (1) the rate of inflation no significant effect on the minimum wage, it can be seen from the test results significance with the $t$ test values obtained $t$ count smaller than $t$ table it was, $-0.079<2.0369$ with a significance value $0938>0.05$. (2) The rate of economic growth does not significantly influence the minimum wage, it can be seen from $t$. count value smaller than the value $t$ table it was, $0.151<2.0369$ with a significance value of $0881<0.05$. (3) The rate of inflation and the rate of economic growth simultaneously no significant effect on the minimum wage, it can be seen from the results of tests of significance by $F$ test values obtained Fcount smaller than the value F.table it was, $0.015<417$ with significant value $0.985<0.05$.
\end{abstract}

Keyword : Inflation rate, economic growth rate, regional minimum wage 


\section{PENDAHULUAN}

Upah adalah imbalan yang diterima pekerja atas jasa kerja yang diberikannya dalam proses memproduksikan barang atau jasa di perusahaan. Perusahaan, pemerintah dan pekerja memiliki kepentingan berbeda terhadap upah. Pekerja memiliki kepentingan terhadap upah untuk memenuhi kebutuhan hidupnya, sedangkan perusahaan berusaha melakukan efisiensi biaya agar dapat memaksimumkan laba. Kepentingan yang berbeda antara perusahaan dengan pekerja mengenai upah, menyebabkan adanya permasalahan antara perusahaan dengan pekerja mengenai upah yang sepantasnya diperoleh. Pemerintah sebagai pihak yang menetapkan kebijakan pengupahan diharapkan mampu memberikan keadilan bagi perusahaan dan tenaga kerja dalam menetapkan upah. Tujuan pemerintah dalam menetapkan kebijakan pengupahan adalah untuk tetap dapat menjamin standar kehidupan yang layak bagi pekerja dan keluarganya, meningkatkan produktivitas dan meningkatkan daya beli masyarakat. Selain itu, kebijakan pengupahan dimaksudkan untuk mendorong pertumbuhan ekonomi dan perluasan kesempatan kerja serta mampu menahan tingkat inflasi. Upah pekerja perlu cukup layak dan terus meningkat supaya dapat meningkatkan kualitas hidup pekerja dan keluarganya. Peningkatan upah dan penghasilan pekerja akan meningkatkan daya beli masyarakat pada umumnya, yang kemudian akan mendorong pertumbuhan ekonomi (Simanjuntak, 2011).

Bagi perusahaan, perbaikan upah merupakan salah satu hal penting untuk dapat meningkatkan kualitas dan produktivitas. Menurut Peraturan Menteri No. 1 Tahun 1999, "Upah Minimum Regional (UMR) merupakan standar minimal pengupahan oleh pengusaha kepada seluruh karyawannya berdasar pada ketetapan di suatu daerah tertentu". Berdasarkan peraturan menteri tersebut, UMR dibagi menjadi 2 yaitu UMR tingkat I yang berada di Provinsi, dan UMR tingkat II di Kota /Kabupaten. Namun Dengan adanya Keputusan Menteri Tenaga Kerja dan Transmigrasi Republik Indonesia No. 226 Tahun 2000 UMR tingkat I telah dirubah menjadi Upah Minimum Provinsi (UMP) dan UMR tingkat II dirubah menjadi Upah Minimum Kabupaten/Kota (UMK). Menurut Peraturan Menteri No. 7 Tahun 2013, Upah Minimum adalah upah bulanan terendah yang terdiri atas upah pokok termasuk tunjangan tetap yang ditetapkan oleh Gubernur sebagai jaring pengaman. UMP adalah upah minimum yang berlaku untuk seluruh kabupaten/kota di satu provinsi. UMK adalah upah minimum yang berlaku di wilayah kabupaten/kota. Menurut UndangUndang No. 13 Tahun 2003 Pasal 88, setiap pekerja berhak memperoleh penghasilan yang memenuhi penghidupan yang layak bagi kemanusiaan. Menurut Saifuddin Bachrun (2012) upah merupakan satusatunya sumber penghasilan dan harus cukup memenuhi kebutuhan hidup bagi mereka dan keluarganya secara wajar atau hidup layak. UMR merupakan salah satu komponen penting dalam kehidupan masyarakat yang digunakan sebagai pemenuhan kebutuhan hidup bagi tenaga kerja, sehingga sangat penting sesuai dengan kebutuhan hidup layak (KHL) masyarakatnya. $\mathrm{KHL}$ adalah standar kebutuhan yang harus dipenuhi oleh seorang pekerja lajang untuk dapat hidup layak baik secara fisik, non fisik dan sosial untuk kebutuhan satu bulan.

Peran pemerintah dalam menetapkan kebijakan pengupahan pada umumnya adalah untuk menjamin standar kehidupan yang layak bagi pekerja dan keluarganya. Menurut Simanjuntak (2011) ketentuan upah minimum dapat ditetapkan berlaku untuk seluruh daerah, di satu negara, atau untuk semua sektor di seluruh daerah, atau berbeda menurut daerah dan sektor. Semakin banyak variasi ketentuan upah minimum semakin lebih mencerminkan kondisi pasarnya, akan tetapi semakin besar beban administrasinya. Walaupun dalam dua dekade terakhir ini UMP dan UMK di Indonesia hampir setiap tahun dinaikkan, namun tingkat upah pada umumnya masih rendah. Menurut Bahcrun (2011) komponenkomponen yang dijadikan dasar penetapan UMP memang sudah rinci dan luas namun dari sisi pencapaian $\mathrm{KHL}$ masih dibawahnya. 
Faktor yang mempengaruhi UMR adalah tingkat inflasi, tingkat pertumbuhan ekonomi dan tingkat suku bunga (Fahmi, 2014). Menurut Murni (2013) tingkat inflasi adalah tingkat perubahan harga secara umum untuk berbagai jenis produk dalam rentang waktu tertentu. Tiga kriteria yang perlu diamati untuk melihat telah terjadinya inflasi, yaitu kenaikan harga, bersifat umum, dan terjadi terus-menerus dalam rentang waktu tertentu. Indikator untuk menghitung tingkat inflasi adalah indeks harga konsumen (consumers price index). Indeks harga adalah rata-rata tertimbang dari harga-harga produk berdasarkan uang yang berlaku di pasar. Indeks harga dapat juga diartikan sebagai ukuran tingkat harga ratarata barang dan jasa. Indeks harga konsumen (consumers price index) adalah indeks harga yang mengukur biaya sekelompok barang dan jasa di pasar. Menurut Sukirno (2002) faktor-faktor yang menimbulkan inflasi ada dua jenis yaitu (1) inflasi tarikan permintaan terjadi apabila sektor perusahaan tidak mampu dengan cepat melayani permintaan masyarakat akan kebutuhan barang dan jasa di dalam pasar dan (2) inflasi desakan biaya adalah masalah kenaikan harga-harga dalam perekonomian yang diakibatkan oleh kenaikan biaya produksi. Menurut Murni (2013) Upaya-upaya untuk mengendalikan inflasi dapat berupa penerapan (1) kebijakan fiskal adalah kebijakan pemerintah untuk mengubah dan mengendalikan penerimaan dan pengeluaran pemerintah melalui APBN (Anggaran Penerimaan dan Belanja Negara) dengan maksud untuk mengatasi masalah yang sedang dihadapi, (2) kebijakan moneter merupakan kebijakan yang dilakukan bank sentral dalam mengatur dan mengendalikan jumlah uang yang beredar, dan (3) kebijakan anti inflasi yang berbiaya rendah, disebut juga kebijakan pendapatan.

Kebijakan pendapatan, yaitu tindakan pemerintah yang berusaha membuat inflasi moderat melalui langkah-langkah langsung, baik melalui persuasi verbal, pengawasan hukum atau insentif-insentif lain

Tingkat pertumbuhan ekonomi adalah suatu perkembangan negara atau daerah yang dapat dilihat dari angka dalam persentase yang memperlihatkan tinggi rendahnya atau cepat lambatnya pertumbuhan ekonomi suatu negara atau daerah dalam periode tertentu dibandingkan periode sebelumnya (Murni, 2013). Pertumbuhan ekonomi sangat ditentukan oleh ketersediaan faktor-faktor produksi dalam suatu negara. Berdasarkan konsep mikro dalam teori produksi, jumlah output sangat ditentukan oleh input-input yang terlibat dalam proses produksi. Secara umum faktor produksi tersebut dapat berupa sumber daya alam (tanah atau lahan, sinar matahari dan lain-lain). Barang modal (berupa barang, mesin, atau uang), tenaga kerja, dan keahlian (managerial skill atau technical skill). Menurut Adisasmita (2013) pertumbuhan ekonomi didefinisikan sebagai peningkatan kapasitas produksi untuk menghasilkan pertambahan output, yang umunya diukur menggunakan Produk Domestik Regional Bruto (PDRB) untuk tingkat daerah. Lebih lanjut dipertegas menurut Adisasmita (2011) PDRB digunakan sebagai indikator untuk mengukur pertumbuhan ekonomi karena (1) PDRB adalah jumlah nilai tambah yang dihasilkan oleh seluruh aktivitas produksi di dalam perekonomian daerah, (2) PDRB dihitung atas dasar konsep arus barang artinya perhitungan PDRB hanya mencangkup nilai produk yang dihasilkan pada suatu periode tertentu, dan (3) batas wilayah perhitungan PDRB adalah daerah (perekonomian domestik).

Pemerintah dalam menetapkan upah minimum mempertimbangkan beberapa faktor antara lain yaitu kebutuhan hidup pekerja dan keluarganya, tingkat upah pada umumnya didaerah yang bersangkutan, biaya hidup dan perubahannya, sistem jaminan sosial nasional, kondisi dan kemampuan perusahaan, serta tujuan nasional seperti mendorong pertumbuhan ekonomi, perluasan kesempatan kerja, dan peningkatan produktivitas (Simanjuntak, 2011). Menurut Ardana, dkk. (2012) salah satu faktor yang mempengaruhi pemberian upah yaitu kondisi perekonomian. Bila kondisi perekonomian sedang maju (boom) maka tingkat upah/kompensasi akan semakin besar, karena akan mendekati kondisi full employment. Sebaliknya jika kondisi perekonomian kurang maju (depresi) maka tingkat upah rendah karena terdapat banyak penganggur (disqueshed un 
employment). Gaol (dalam Kristanto, 2013:12) apabila terjadi peningkatan produktivitas tenaga kerja yang diukur dengan output PDRB maka upah minimum ditingkatkan. Menurut Saiffudin Bachrun (2012) perubahan upah yang ditetapkan pemerintah berkaitan erat dengan produktivitas, baik secara langsung maupun tidak langsung. Kistanto (2013) menyimpulkan bahwa PDRB berpengaruh positif terhadap UMK. Menurut Mankiw (2006) penyesuaian harga secara bertahap, mempengaruhi penetapan upah. Jumlah uang beredar yang lebih kecil menurunkan permintaan agregat, yang selanjutnya memaksa penurunan proporsional upah nominal untuk mempertahankan kesempatan kerja. Ketika jumlah uang beredar banyak maka akan dapat meningkatkan upah. Menurut Murni (2013) salah satu kebijakan pemerintah untuk mengatasi inflasi adalah dengan mengatur tingkat upah. Ulfa (2014) menyimpulkan bahwa laju inflasi berpengaruh positif terhadap UMR.

Provinsi Bali merupakan salah satu provinsi di Indonesia yang mengalami permasalahan upah minimum. Pada hari Kamis, 19 November 2015 Sekelompok buruh di Bali khususnya di Denpasar, menggelar aksi unjuk rasa yang bertujuan untuk menuntut UMR Provinsi Bali sama dengan UMR DKI Jakarta (sumber data: http://regional.kompas.com/read/2015/11/9/ 12490681/Demo.Buruh.di.Bali.tuntut.UMR.d isamakan.dengan.DKI.Jakarta).

Berdasarkan penelitian awal diketahui bahwa, UMR di Bali masih rendah. Pada tahun 2010 UMR sebesar Rp 829.316,00 dan KHL Provinsi Bali sebesar Rp 959.232,00, pada tahun 2011 UMR sebesar Rp 890.000,00 dan KHL Provinsi Bali sebesar Rp 711.099,00, pada tahun 2012 UMR sebesar Rp 967.200,00 dan KHL Provinsi Bali sebesar Rp 1.101.766,00, pada tahun 2013 UMR sebesar Rp 1.130.779,00 dan KHL Provinsi Bali sebesar Rp 2.117.000,00, pada tahun 2014 UMR sebesar Rp 1.542.600,00 dan KHL Provinsi Bali sebesar Rp 1.396.234,00, pada tahun 2015 UMR sebesar Rp 1.621.172,00 dan KHL Provinsi Bali sebesar Rp 1.612.818,00 (sumber data: www.bps.go.id). Sehingga pada tahun 2010 sampai dengan tahun 2013
UMR Provinsi Bali belum sesuai dengan harapan masyarakat untuk mampu memenuhi kebutuhan hidupnya secara layak, dan pada tahun 2014 sampai dengan tahun 2015 UMR sudah sesuai dengan KHL. Namun perkembangan UMR Provinsi Bali yaitu dari tahun 2008 sampai tahun 2015 mengalami fluktuasi yaitu $(9,75 \%)$, $(11,33 \%), \quad(9,12 \%), \quad(7,32 \%), \quad(8,71 \%)$, $(22,07 \%),(30,62 \%),(5,09 \%)$ (sumber data: www.bps.go.id).

Permasalahan UMR Provinsi Bali yang belum sesuai dengan $\mathrm{KHL}$ dan perkembangan UMR yang mengalami fluktuasi diduga disebabkan oleh tingkat inflasi dan tingkat pertumbuhan ekonomi yang mengalami fluktuasi. Tingkat inflasi di Provinsi Bali Pada tahun 2008 sampai dengan 2015 yaitu (9,62\%), (4,37\%), $(8,10 \%), \quad(3,75 \%), \quad(4,71 \%), \quad(7,35 \%)$, $(8,03 \%), \quad(2,70 \%)$. Tingkat pertumbuhan ekonomi di Provinsi Bali pada tahun 2008 sampai dengan 2015 yaitu (5,97\%), (5,33\%), $5,83 \%),(6,66 \%),(6,96 \%)(6,69 \%),(6,72 \%)$, $(6,04 \%)$ (sumber data: Badan Pusat Statistik (BPS) Provinsi Bali).

Berdasarkan dari latar belakang dan kajian teori di atas, maka dapat dikaji permasalahan yang ingin diteliti, penelitian ini memfokuskan pada "Pengaruh Tingkat Inflasi, dan Tingkat Pertumbuhan Ekonomi terhadap Upah Minimum Regional (UMR) di Provinsi Bali pada Tahun 2008-2015", sehingga rumusan masalah dalam penelitian ini adalah (1) apakah terdapat pengaruh tingkat inflasi terhadap UMR di Provinsi Bali pada tahun 2008-2015, (2) apakah terdapat pengaruh tingkat pertumbuhan ekonomi terhadap UMR di Provinsi Bali pada tahun 2008-2015, dan (3) apakah terdapat pengaruh tingkat inflasi, dan tingkat pertumbuhan ekonomi secara simultan terhadap UMR di Provinsi Bali pada tahun 2008-2015.

Berdasarkan rumusan masalah di atas, maka yang menjadi tujuan penelitian ini adalah untuk mengetahui (1) pengaruh tingkat inflasi terhadap UMR di Provinsi Bali pada tahun 2008-2015, (2) pengaruh tingkat pertumbuhan ekonomi terhadap UMR di Provinsi Bali pada tahun 2008-2015, dan (3) pengaruh tingkat inflasi, dan tingkat pertumbuhan ekonomi secara simultan 
terhadap UMR di Provinsi Bali pada tahun 2008-2015.

\section{METODE PENELITIAN}

Jenis penelitian ini adalah penelitian kausal dengan pendekatan kuantitatif. Penelitian kausal merupakan pendekatan ilmiah terhadap pengambilan keputusan manajerial dan ekonomi yang bertujuan untuk mendapatkan bukti hubungan sebab akibat atau pengaruh dari variabel-variabel penelitian. Menurut Sugiyono (2007) desain kausalitas dapat dilakukan dengan langkahlangkah sebagai berikut (1) merumuskan masalah, (2) landasan teori, (3) merumuskan hipotesis, (4) melakukan penelitian, (5) mengumpulkan data dan analisis data, dan (6) menyusun laporan dan menyimpulkan. Penelitian ini dilakukan untuk mengetahui pengaruh tingkat inflasi dan tingkat pertumbuhan ekonomi terhadap UMR. Variabel bebas dalam penelitian ini adalah tingkat inflasi (X1) dan tingkat pertumbuhan ekonomi (X2), sedangkan yang termasuk dalam variabel terikat adalah UMR (Y). Adapun subjek dalam penelitian ini adalah Provinsi Bali. Objek penelitian ini adalah tingkat inflasi, tingkat pertumbuhan ekonomi dan UMR Provinsi Bali. Jenis data yang digunakan dalam penelitian ini adalah data kuantitatif. Menurut Sugiyono (2010) data kuantitatif adalah jenis data yang berupa angka-angka (dapat diukur atau dihitung). Data yang digunakan dalam penelitian ini adalah tingkat inflasi, tingkat pertumbuhan ekonomi dan UMR.

Sumber data yang digunakan dalam penelitian ini adalah data sekunder. Data sekunder adalah sumber data penelitian yang diperoleh secara tidak langsung melalui BPS Provinsi Bali. Metode yang digunakan dalam pengumpulan data pada penelitian ini adalah metode dokumentasi. Metode dokumentasi adalah metode yang dipergunakan untuk mengumpulkan data mengenai hal-hal atau variabel yang berupa catatan. Dalam penelitian ini, dokumentasi berupa dokumen mengenai tingkat inflasi, tingkat pertumbuhan ekonomi dan UMR dari BPS Provinsi Bali. Metode analisis data yang digunakan dalam penelitian ini adalah analisis regresi dengan variabel dummy dan pengolahan data dilakukan dengan menggunakan program SPSS 16.0 for windows. Menurut Yudiaatmaja (2013) analisis regresi dengan variabel dummy adalah regresi yang mengandung data berbentuk nominal (dummy). Data nominal adalah data yang hanya bermanfaat untuk membedakan atau mengelompokkan. Misalnya data jenis kelamin terdiri dari pria dan wanita. Data dummy lainnya bisa berupa data berat, data tinggi, data nilai, dan sebagainya. Menurut Santosa (2005), regresi dummy digunakan pada persamaan regresi yang variabel bersifat kualitatif. Variabel yang bersifat kualitatif ini bisa merupakan variabel kategorik.

Sebelum melakukan analisis regresi dengan variabel dummy, maka terlebih dahulu dilakukan uji asumsi klasik. Uji asumsi klasik digunakan untuk mengetahui apakah persamaan dari analisis regresi bisa digunakan untuk memberikan prediksi terhadap variabel yang diteliti. Menurut Santosa (2009) terdapat lima uji asumsi klasik yang harus diuji yaitu (1) uji normalitas bertujuan untuk menguji apakah dalam model regresi, variabel pengganggu atau residual mempunyai distribusi normal, (2) uji multikoloniaritas bertujuan untuk menguji apakah ada gejala korelasi antar variabel independen (3) uji heteroskedastisitas bertujuan menguji apakah varians dari residual dari satu pengamatan ke pengamatan yang lain tetap sama atau berbeda. (4) uji autokorelasi bertujuan menguji apakah dalam suatu model regresi linear ada korelasi antar kesalahan pengganggu (residual) pada periode $t$ dengan kesalahan pada periode $t-1$ (sebelumnya), (5) uji linearitas bertujuan menguji apakah persamaan hubungan antara variabel independen dan dependen linear. Analisis regresi dengan variabel dummy terdapat dua jenis pengujian yaitu uji t dan uji F. Uji t digunakan untuk mengetahui besarnya pengaruh satu variabel bebas yang terdiri dari tingkat inflasi dan tingkat pertumbuhan ekonomi secara individual dalam menerangkan variabel terikat yaitu UMR. Uji $F$ bertujuan untuk mengetahui besarnya pengaruh semua variabel bebas secara bersama-sama terhadap variabel terikat. Uji F difungsikan untuk mengetahui kemampuan variabel bebas yang terdiri dari tingkat inflasi dan tingkat pertumbuhan ekonomi secara bersama-sama dalam 
menjelaskan UMR. Selain uji t dan uji F, juga dilakukan analisis determinasi yaitu untuk mengetahui besarnya pengaruh tingkat inflasi dan tingkat pertumbuhan ekonomi terhadap UMR.

\section{HASIL PENELITIAN DAN PEMBAHASAN Hasil Penelitian}

Pengaruh Tingkat Inflasi terhadap UMR di Provinsi Bali pada Tahun 2008-2015 yang dianalisis dengan menggunakan uji statistik $t_{\text {tes }}$ dengan menggunakan program SPSS 16.0 for windows. Hasil analisis menunjukkan besarnya pengaruh Tingkat Inflasi terhadap UMR dapat dilihat pada tabel

Tabel 1. Hasil uji t untuk variabel tingkat inflasi terhadap UMR Provinsi Bali

\begin{tabular}{|c|c|c|c|c|c|c|}
\hline \multirow[b]{3}{*}{ Model } & \multicolumn{6}{|c|}{ Standardized } \\
\hline & \multicolumn{2}{|c|}{ Unstandardized Coefficients } & \multicolumn{4}{|c|}{ Coefficients } \\
\hline & $B$ & Std. Error & Beta & & $\mathrm{T}$ & Sig. \\
\hline${ }^{1}$ (Constant) & 3.192E6 & 209797.274 & & & 15.217 & .000 \\
\hline Tingkat Inflasi & -1606.698 & 20392.697 & & -.015 & -.079 & .938 \\
\hline
\end{tabular}

Tabel 1 memperlihatkan bahwa variabel Tingkat Inflasi tidak berpengaruh signifikan terhadap UMR karena dilihat dari nilai $t_{\text {hitung }}=-0.079<t_{\text {tabel }}=2.0369$ atau $p$ value $=0.938>\alpha=0.05$ maka $\mathrm{H}_{\mathrm{a}}$ ditolak. Dapat disimpulkan bahwa variabel Tingkat inflasi tidak memiliki pengaruh yang signifikan terhadap UMR di Provinsi Bali Tahun 2008-2015.
Pengaruh Tingkat Pertumbuhan Ekonomi terhadap UMR di Provinsi Bali pada Tahun 2008-2015 yang dianalisis dengan menggunakan uji statistik t tes dengan menggunakan program SPSS 16.0 for windows. Hasil analisis menunjukkan besarnya pengaruh Tingkat Pertumbuhan Ekonomi terhadap UMR dapat dilihat pada tabel

Tabel 2. Hasil uji t untuk variabel tingkat pertumbuhan ekonomi terhadap UMR Provinsi Bali

Standardized

\begin{tabular}{|c|c|c|c|c|c|}
\hline \multirow[b]{2}{*}{ Model } & \multicolumn{2}{|c|}{ Unstandardized Coefficients } & \multirow{2}{*}{$\begin{array}{l}\text { Coefficients } \\
\text { Beta }\end{array}$} & \multirow[b]{2}{*}{$\mathrm{t}$} & \multirow[b]{2}{*}{ Sig. } \\
\hline & $B$ & Std. Error & & & \\
\hline 1 (Constant) & 3.192E6 & 209797.274 & & 15.217 & .000 \\
\hline $\begin{array}{l}\text { Tingkat Pertumbuhan } \\
\text { Ekonomi }\end{array}$ & -7991.170 & 52930.408 & -.028 & -.151 & .881 \\
\hline
\end{tabular}

Tabel 2 memperlihatkan bahwa variabel tingkat pertumbuhan ekonomi tidak memiliki pengaruh yang signifikan terhadap UMR karena dilihat dari nilai thitung $=0.151<$ $t_{\text {tabel }}=2.0369$ atau $p$-value $=$ $0.881<\alpha=0.05$, maka Ha ditolak. Jadi dapat disimpulkan bahwa variabel tingkat pertumbuhan ekonomi tidak memiliki pengaruh yang signifikan terhadap UMR di Provinsi Bali Tahun 2008-2015.
Pengaruh Tingkat Inflasi dan Tingkat Pertumbuhan Ekonomi secara Simultan terhadap UMR di Provinsi Bali pada Tahun 2008-2015 dilakukan dengan menggunakan uji statistik $F_{\text {tes }}$ dengan menggunakan program SPSS 16.0 for windows. Hasil analisis menunjukkan besarnya pengaruh tingkat inflasi dan tingkat pertumbuhan ekonomi secara simultan terhadap UMR dapat dilihat pada tabel 3 . 
Tabel 3. Hasil perhitungan uji F tingkat inflasi dan tingkat pertumbuhan ekonomi terhadap UMR

\begin{tabular}{|c|c|c|c|c|c|c|}
\hline Model & & Sum of Squares & Df & Mean Square & $\mathrm{F}$ & Sig. \\
\hline \multirow[t]{3}{*}{1} & Regression & 3.391E10 & 2 & 1.696E10 & .015 & $.985^{a}$ \\
\hline & Residual & $3.184 \mathrm{E} 13$ & 29 & $1.098 \mathrm{E} 12$ & & \\
\hline & Total & $3.188 \mathrm{E} 13$ & 31 & & & \\
\hline
\end{tabular}

Berdasarkan hasil analisis pada tabel 3 menunjukan bahwa Fhitung $=0.015$ $<$ Ftabel $=4.17$ atau $p$-value $=0.985>\alpha=$ 0,05 . Hal ini berarti Ha ditolak, jadi dapat disimpulkan bahwa variabel tingkat inflasi dan tingkat pertumbuhan ekonomi secara simultan tidak memiliki pengaruh yang signifikan terhadap variabel UMR.
Untuk mengetahui besarnya pengaruh tingkat inflasi dan tingkat pertumbuhan ekonomi terhadap UMR, maka dapat digunakan analisis koefisien determinasi (Adjusted $R$ Square). Besarnya koefisien determinasi (Adjusted $R$ Square) dapat dilihat pada tabel 4.

Tabel 4. Hasil Perhitungan Koefisien Determinasi (Adjusted RSquare)

\begin{tabular}{lrrrrr}
\hline Model & $\mathrm{R}$ & $\mathrm{R}$ Square & Adjusted R Square & \multicolumn{2}{c}{ Std. Error of the Estimate } \\
1 & $.033^{\mathrm{a}}$ & .001 & -.068 & & $1.04790 \mathrm{E} 6$ \\
\hline & & & & moderat & merupakan tingkat inflasi yang \\
& Berdasarkan hasil analisis pada tabel & paling rendah. Menurut &
\end{tabular}

4 dengan menggunakan program SPSS 16.0 for windows menunjukkan bahwa besar pengaruh tingkat inflasi dan tingkat pertumbuhan ekonomi terhadap variabel UMR secara simultan sebesa $-0,68$ sehingga sumbangan pengaruh untuk variabel tingkat inflasi (X1) dan tingkat pertumbuhan ekonomi (X2) terhadap UMR (Y) secara simultan adalah sebesar 0 . Hal ini berarti UMR di Provinsi Bali Tahun 20082015 tidak dipengaruhi oleh variabel tingkat inflasi dan tingkat pertumbuhan ekonomi. Sehingga UMR di Provinsi Bali dipengaruhi oleh faktor lain.

\section{Pembahasan}

Hasil penelitian yang menunjukkan tidak ada pengaruh tingkat inflasi (X1) terhadap UMR (Y) di Provinsi Bali Tahun 2008-2015 mendukung hasil temuan empiris dari Kistanto (2013) yang menyatakan bahwa tingkat inflasi tidak mempengaruhi UMR. Hal tersebut, karena tingkat inflasi di Provinsi Bali per tri wulan dari tahun 20082015 sebagian besar yaitu $96,87 \%$ termasuk dalam tingkat inflasi moderat.Tingkat inflasi

Murni (2013) kebijakan anti inflasi yang berbiaya rendah yaitu kebijakan-kebijakan yang berusaha menurunkan inflasi tanpa terjadi kenaikan tingkat pengangguran. Kebijakan anti inflasi yang berbiaya rendah, disebut juga kebijakan pendapatan. Kebijakan pendapatan, yaitu tindakan pemerintah yang berusaha membuat inflasi moderat melalui langkah-langkah langsung, baik melalui persuasi verbal, pengawasan hukum atau insentif-insentif lain dan tindakan langsung pemerintah seperti kebijakan pengendalian harga dan upah di pasar produk dan pasar tenaga kerja. Kebijakan akan sangat berarti bagi kegiatan ekonomi, apabila bisa menjaga tingkat inflasi berada ditingkat yang sangat rendah. Sehingga tingkat inflasi di Provinsi Bali yang rendah dan sudah sesuai dengan tujuan pemerintah, maka tingkat inflasi tidak mempengaruhi UMR.

Hasil penelitian yang menunjukkan tidak ada pengaruh tingkat pertumbuhan ekonomi (X2) terhadap UMR (Y) di Provinsi Bali Tahun 2008-2015 ini tidak mendukung 
teori Fahmi (2014) yang menyatakan bahwa UMR dipengaruhi oleh tingkat pertumbuhan ekonomi. Hal tersebut, karena tingkat pertumbuhan ekonomi di Provinsi Bali per tri wulan dari tahun 2008-2015 sebagian besar mengalami pertumbuhan yang lambat dan lapangan usaha yang dominan memberikan kontribusi dalam peningkatan pertumbuhan ekonomi adalah sektor perdagangan, hotel dan restoran, serta pertanian, peternakan, kehutanan dan perikanan. Menurut Murni (2013) secara umum daerah yang belum maju atau lambat pertumbuhannya adalah daerah agraris yang PDRB didominasi oleh hasil pertanian. Menurut Bachrun (2012) perkembangan sektor industri modern dan majunya pertumbuhan ekonomi akan mampu melakukan perbaikan tingkat upah dan meningkatkan standar hidup masyarakatnya, sehingga hal tersebut, menyebabkan tingkat pertumbuhan ekonomi tidak mempengaruhi UMR.

Hasil penelitian menunjukkan tidak ada pengaruh yang signifikan tingkat inflasi (X1) dan tingkat pertumbuhan ekonomi (X2) secara simultan terhadap UMR (Y) di Provinsi Bali Tahun 2008-2015. Hasil penelitian ini tidak mendukung teori Fahmi (2014) yang menyatakan bahwa faktor yang mempengaruhi UMR adalah tingkat inflasi dan tingkat pertumbuhan ekonomi. Hal tersebut, karena tingkat inflasi yang sudah rendah dan sesuai dengan tujuan pemerintah serta lambatnya tingkat pertumbuhan ekonomi di Provinsi Bali, sehingga tingkat inflasi dan tingkat pertumbuhan ekonomi tidak mempengaruhi UMR di Provinsi Bali pada tahun 2008-2015. Selain itu karena ada berbagai faktor lain yang mempengaruhi upah. Menurut Bachrun (2011) salah satu faktor yang mempengaruhi tingkat upah adalah pengangguran. Pengangguran yang masih tinggi di Provinsi Bali yaitu tahun 2013 sebesar 41.482 orang dan 2014 sebesar 44.126 orang dan tahun 2015 sebesar 47.210 orang (sumber data: BPS Provinsi Bali), sehingga dengan pengangguran yang terus meningkat mungkin hal tersebut yang mempengaruhi tingkat upah di Provinsi Bali. Menurut Fahmi (2014) faktor yang mempengaruhi UMR salah satunya tingkat suku bunga.

\section{PENUTUP \\ Simpulan}

Berdasarkan hasil penelitian dan pembahasan maka dapat disimpulkan sebagai berikut.

(1) Tingkat inflasi tidak berpengaruh singnifikan secara parsial terhadap UMR di Provinsi Bali pada Tahun 20082015. Hal tersebut ditunjukan dari hasil analisis tes yang menunjukkan bahwa nilai thitung $=-0.079<t_{\text {tabel }}=2.0369$ atau $p$-value $=0.938>\alpha=0.05$.

(2) Tingkat pertumbuhan ekonomi tidak berpengaruh signifikan secara parsial terhadap UMR di Provinsi Bali pada Tahun 2008-2015. Hal tersebut ditunjukan dari hasil analisis tes yang menunjukan bahwa nilai thitung $=$

$0.151<\mathrm{t}_{\text {tabel }}=2.0369$ atau $\mathrm{p}$-value $=$ $0.881<\alpha=0.05$.

(3) Tingkat inflasi dan tingkat pertumbuhan ekonomi tidak berpengaruh signifikan secara simultan terhadap UMR di Provinsi Bali pada Tahun 2008-2015. Hal tersebut ditunjukan dari hasil analisis $F_{\text {tes }}$ yang menunjukkan bahwa Fhitung $=0.015<$ Ftabel $=4.17$ atau $p$ value $=0.985>\alpha=0,05$.

\section{Saran}

Berdasarkan simpulan di atas, maka dapat dikemukakan beberapa saran sebagai berikut.

(1) Bagi Akademik

Bagi peneliti lain yang bermaksud melakukan penelitian di bidang Ketenagakerjaan khususnya meneliti tentang Upah Minimum Regional, diharapakan melakukan penelitian lebih lanjut dan mendalam untuk mengembangkan penelitian ini dengan mengkaji aspek-aspek lain yang mempengaruhi UMR dan melakukan penelitian dengan menggunakan waktu yang lebih lama serta subyek yang lebih banyak.

(2) Bagi Pemerintah Provinsi Bali

$$
\text { Bagi pemerintah Provinsi Bali }
$$

diharapkan dalam menetapkan UMR 
p-ISSN : 2599-1418

e-ISSN : 2599-1426

memperhatikan tingkat inflasi dan tingkat pertumbuhan ekonomi, sehingga UMR bisa memenuhi kebutuhan hidup masyarakat dengan layak dan sejahtera. Bagi Badan Pusat Statistik Provinsi Bali diharapkan dapat menyediakan data PDRB pada tingkat perbulan.

\section{DAFTAR PUSTAKA}

Adisasmita, Rahardjo. 2011. Pembiayaan Pembangunan Daerah. Yogyakarta: Graha IImu

2013. Teori-Teori Pembangunan Ekonomi. Yogyakarta: Graha IImu

Ardana, I Komang,dkk. 2012. Manajemen Sumber Daya Manusia. Yogyakarta: Graha IImu

Bachrun,Saifuddin. $2012 . \quad$ Desain Pengupahan untuk Perjanjian Kerja Bersama. Jakarta: PPM.

--------. 2011. MenghitungTunjangan Insentif Bonus dan Fasilitas. Jakarta: PPM.

Badan Pusat Statistik. 2015. Bali dalam Angka 2015. Denpasar :BPS

2015. Data dan Informasi Indeks Harga Konsumen, PDRB dan UMR Provinsi Bali 2008-2015. Denpasar: BPS

Fahmi, Irham. 2014. Kewirausahaan. Bandung: Alfabeta

Keputusan Menteri Tenaga Kerja dan Transmigrasi Republik Indonesia No. 226 Tahun 2000 Tentang Perubahan Pasal 1, Pasal 3, Pasal 4, Pasal 8, Pasal 11, Pasal 20 dan Pasal 21 Peraturan Menteri Tenaga Kerja

Kistanto, Ilham. 2013. Analisis Penetapan Upah Minimum di Jember. Tersedia pada(http://repository.unej.ac.id/bitst ream/handle/123456789/5678/llham $\% 20$ Kistanto\%20$\% 20090810101120$.pdf?sequence= 1 diakses tanggal 12 Juni 2016).
Jurnal Pendidikan Ekonomi Undiksha

Volume 9 No.1 Tahun: 2017

Lestari, Sri.2015. Demo, Buruh di Bali Tuntut UMR disamakan dengan DKI Jakarta. tersedia pada http://regional.kompas.com/read/201 5/11/19/12490681/Demo.Buruh.di.B ali.Tuntut.UMR.disamakan.dengan. DKI.Jakarta (diakses pada tanggal 2 Juni 2016).

Murni, Asfia. 2013. Ekonomika Makro. Bandung: PT Refika Aditama

Mankiw,Gregory.2006.Makroekonomi. Jakarta : Erlangga.

Peraturan Menteri No. 01 Tahun 1999 Tentang Upah Minimum

Peraturan Menteri No. 7 Tahun 2013 Tentang Upah Minimum

Santosa, Budi, Purbayu dan Ashari. 2005. Analisis Statistik dengan Microsoft Excel dan SPSS. Yogyakarta: ANDI.

Simanjuntak, Payaman J.2011.Manajemen Hubungan Industrial. Jakarta: Fakultas Ekonomi Universitas Indonesia

Sugiyono. 2010. Metode Penelitian Kuantitatif Kualitatif dan $R \& D$. Bandung: Alfabeta.

Sukirno, Sadono. 2002. Pengantar Teori Makroekonomi. Jakarta: PT. Raja Grafindo Perkasa.

2004. Makro Ekonomi Modern. Jakarta: PT. Raja Grafindo Perkasa.

Ulfa Triana, Novia. 2014. "Penerapan Analisis Regresi Panel pada Pemodelan Angka Upah Minimum Regional (UMR) Propinsi di Indonesia pada Periode Tahun 20082012". Tersedia pada http://statistik.studentjournal.ub.ac.id /index.php/statistik/article/view/176/1 96 (diakses pada tanggal 25 Mei 2016)

Undang-Undang No. 13 Tahun 2003 Tentang Ketenagakerjaan 
p-ISSN : 2599-1418

e-ISSN : 2599-1426

www.bali.bps.go.id (diakses pada tanggal 25 Desember 2016)

www.bps.go.id (diakses pada tanggal 18 Januari 2017)
Jurnal Pendidikan Ekonomi Undiksha Volume 9 No.1 Tahun: 2017

Yudiaatmaja, Fridayana. 2013. Analisis Regresi Dengan Menggunakan Aplikasi Komputer Statistik SPSS. Singaraja: PT Gramedia Pustaka Utama,Jakarta. 